\title{
PROGRESSING STUDENTS' MOTIVATION IN LEARNING ENGLISH BY USING HYPNOSIS (HYPNOLEARNING) AT STUDENTS OF STAN 2 OF JILC PERINTIS, MAKASSAR
}

\author{
Hamzar \\ STIE Muhammadiyah Mamuju \\ hamzar_america@yahoo.com
}

\begin{abstract}
This article provides a description of the students' motivation in learning English by using hypnosis (hypnolearning) at the students of STAN 2 of JILC Perintis, Makassar 2010/2011.The population of the research consisted of the students of STAN 2 of JILC Perintis, Makassar in academic year of 2010/2011. It consisted of one class. The number of the students was 20 and the sample of this research was total sampling. It means that all students of STAN 2 of JILC Perintis, Makassar were taken as samples namely 20 students. In this research, the data were collected by using questionnaire. The questionnaire was used to obtain data on students' motivation by using hypnosis (hypnolearning). It consisted of 20 items. Based on the data obtained, this article discovered that students were motivated in learning English by using hypnosis (hypnolearning). The data showed that the students always choose "agree" in every item of the questionnaire which was given. It indicated that the level of the students' motivation of STAN 2 of JILC Perintis, Makassar in learning English by using hypnosis (hypnolearning) was "agree".
\end{abstract}

\section{A. INTRODUCTION}

The students will attain the goal of study if they have strong motivation in learning.
Motivation plays an important role for students' success in learning. The most
important thing to get the goal of learning is motivation. Motivated students are more excited to participate in the learning process. Meanwhile, students who are not motivated will not able to learn effectively. Therefore, the teacher should be able to motivate the students towards achieving their goal. Dale Carnegie in Mario Seto (2009: 2) says that success is getting what you want. Happiness is wanting what you get.

Nowadays, one of the institutions in Makassar which uses hypnosis (hypnolearning) as a technique to motivate the students in learning all subjects is JILC. Some parents agree that it really helps their children to get motivated in learning some subjects. However, some other parents disagree with hypnosis (hypnolearning) applied at JILC because they think that hypnosis (hypnolearning) is considerably dangerous and it is regarded as "black magic". 
Hypnosis (hypnolearning) has been applying in JILC since the beginning of 2009. In JILC, all the students gain hypnolearning program once a month but the tutors can apply hypnosis (hypnolearning) anytime they want. This program is how to change students' negative thought by using subconscious mind. Further information about JILC, you can search at www.jilcmakassar.com.

Based on introduction above, the objective of the research is the researcher wants to know whether hypnosis (hypnolearning) can increase motivation of JILC's students in learning English. One of the most challenging aspects of becoming a teacher is to motivate students in learning, and how to handle the less motivated students, unmotivated students or the naughty students. Even though the teachers have a good performance in teaching, the students may have lack of motivation to study due to some factors such as laziness, hopelessness, naughtiness, and other problems that lead to unsuccessful teaching. To solve this problem is not easy. The teachers cannot be harsh to face this problem because it will become failed. Advice is not useful again to change students' mind so by using hypnosis (hypnolearning), the researcher assumes that the teachers can solve that problem.

\section{B. REVIEW OF LITERATURE}

\section{Student}

Student is a person who is studying at formal education such as at school, college or university, and someone who joins a particular subject at course in non-formal education. Knowing why learners intend to improve their English will mean to find out how they feel about studying English at the beginning of the course. It becomes necessary input as learners normally to bring their own beliefs, goals, attitudes, and decisions which influence how to approach the process of learning.

\section{Motivation}

Mc. Donald in Jamarah (2008:148) says motivation is energy change within the person characterized by affective arousal and anticipatory goal reactions. Jamarah (2008: 152) says that motivation is indication of psychology which forms encouragement appeared from self of somebody through conscious or unconscious to do activity with certain purpose. Purwanto (1992: 71) says that motivation is "instigation" or the activity which is bewared to stimulate someone's behavior in order that his/her hearth is moved to do something so he/she attains 


\section{Hamzar, Pogressing Students' Motivation in Learning English....}

result or certain purpose. Duncan in Purwanto (1992: 72) states that someone is professional administration. In his book, Organizational Behavior, he states that in management concept, motivation means effort which is bewared to stimulate someone behavior in order that someone increase his/her ability maximally to attain organizational purpose. According Vroom in Purwanto (1992: 72) that motivation shapes the tone process stimulating individual choices to various forms of activity which is intended to. Hoy and Miskel in their book "Educational Administration" (1982: 137) state that motivation can be defined as power which is complex, encouragements, needs, and tension states, or other mechanisms which start and keep activities which is wished into attainment personal purposes. Uno (2008:9) says that motivation is encouragement which appears because there is stimulus from inside or outside so someone wants to change his/her certain behavior better than before.

\section{Hypnosis}

Rusli and Wijaya (2009: 34) say that the word hypnosis is generated from Greek 'hypnos' which means slept in trace condition. Nevertheless, hypnosis is not like sleep condition because in hypnosis term, somebody's mind is in focusing condition and can hear words said by the hypnotist clearly. Besides, someone can speak and move to follow somebody's desire that hypnotises. A big Indonesian Dictionary (2008: 501) in Wong and Hakim (2009: 2) explains that the meaning of the word "hypnosis" is the condition like sleep because of suggestion which is in standard of beginning and someone is under influence from person who gives suggestion, but the next standard becomes unconscious anymore. Wong and Hakim (2009: 3) say that hypnosis can be defined as one of relaxed conditions, focuses, or concentrations. Gunawan (2007: 10) says that hypnosis is comfortable and enjoyable situation in controlled environment. Brandon (2009: 2) says that hypnosis is a method that makes your conscious mind realizes from boredom to become relaxed and to stop to think. It is almost the same condition when you wake up from sleep at night before you exactly fall asleep. According British Medical Association as a result of their investigation into the use of hypnosis in medicine in 1955 (BMA, 1955, 1982) in Burrows, Robb O Stanley and Peter B Bloom (2001:4), hypnosis is a temporary condition of altered perception in the subject which may be induced by another person and in which a variety of phenomena may appear spontaneously or in response to verbal or other stimuli. These phenomena include alterations in consciousness and memory, increased susceptibility to suggestion, the production in the subject of responses, and unfamiliar ideas to him in his normal state of mind. Further 
phenomena such as anesthesia, paralysis and rigidity of muscles and vasomotor changes can be produced and removed in the hypnotic state. Shuttleworth (2004: 4) states that the word "hypnos" comes from the Greek and means "to sleep". However, a totally natural state of mind in fact is very different from sleep. Setiawan (2009: 26) says that hypnosis comes from word "hypnos". Hypnos is a name of the Greek sleep God. According to Putra (2010: 25) that the word hipnotis in Indonesian language comes from word "hypnosis" which forms basic word from "hypnos", which means sleep God in the Greek legend. The term "hypnosis" was firstly introduced by Dr. James Braid, one of the researches of hypnosis comes from England in $19^{\text {th }}$ century. Hypnosis forms condition where someone is subconscious condition and he/she still listens and feels his/her surrounding area. Rusli and Wijaya (2009:39) explain that human beings have two brains namely big brain (right brain) and small brain (left brain). The functions of big brain are: to save visual memory, experience, art, creativity, belief, suggestion and imagination. The functions of small brain are: to absorb things which are considered as logic or analysis like sequence of number and alphabet, day and night, and some the other logical things.

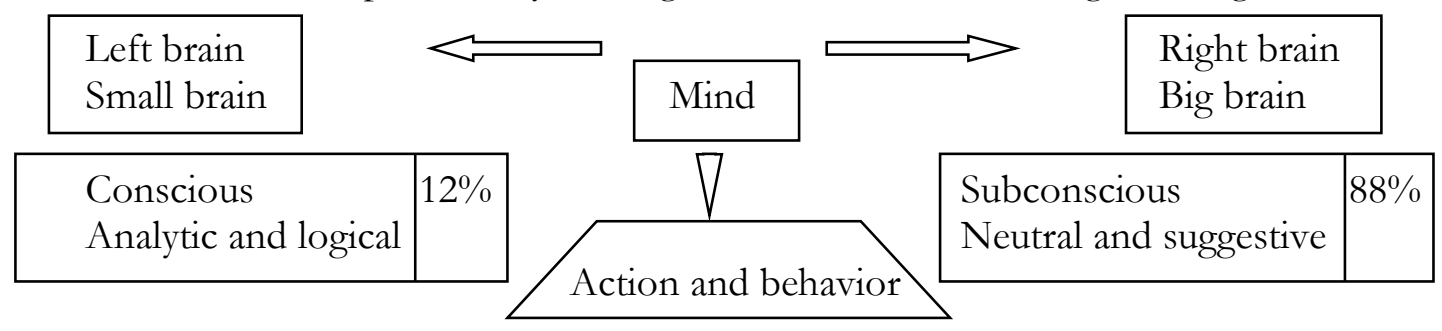

Human beings often use left brain to think and to take decision. The power of left brain is $12 \%$ from total of brain functions. It can be imagined that if you are able to use a part of right brain, you will become creative and genius person.

Rusli and Wijaya (2009: 3, 17, 89) say that hypnosis is one of the effective ways to lose bad habits and change them better. Hypnosis is used to give motivation to subconscious mind to corporate with conscious goal and desires to help reaching success which is wanted. Wong and Hakim (2009:22-47)state that hypnosis (hypnolearning) is classified in some structures or steps namely pre induction, induction, deepening, depth level test, suggestion, termination, post hypnosis, and normal condition.

The purpose of this study was to examine whether the use of hypnosis (hypnolearning) increase students' motivation in learning English. The researcher formulates the research questions as follows: Does the students' motivation increase in learning English by using hypnosis (hypnolearning) at students of STAN 2 of JILC Perintis, Makassar 2010/2011? Is 


\section{Hamzar, Pogressing Students' Motivation in Learning English....}

hypnosis (hypnolearning) eligible to be used in education systems to motivate the students in learning?

\section{METHOD}

The research design used in this research was descriptive. It covered description about the influence of hypnosis (hypnolearning) on students' motivation in studying English at JILC. The research was conducted at students of STAN 2 of JILC Perintis, Makassar. The populations of this research were the students of STAN 2 of JILC Perintis, Makassar 2010/2011 which consisted of 20 students. This research used total sampling. It means that all students of STAN 2 of JILC Perintis, Makassar were taken as sample namely 20 students. The data were collected by using questionnaire. The questionnaire was used to obtain data on the students' motivation after getting hypnosis (hypnolearning) when the researcher taught his students. The questionnaire consisted of 20 items. The students just marked a checklist on the answer given for the questionnaire. To collect the data, the researcher had done the following procedures:

1. Explaining the aims of the research to the students.

2. Doing treatments with progressing students' motivation by using hypnosis (hypnolearning) for eight meetings. The total treatments including questionnaire distribution were 8 times for 8 meetings. Hypnosis (hypnolearning) had been conducted during teaching in the last session of the lesson for 10 minutes before the bell rang to take a break. After doing hypnosis (hypnolearning), the researcher turned on a video by using notebook (laptop) about " The power of Subconscious Mind, Physical Defect Olympiad, Brain Power and Visualization" for 5-10 minutes. In addition, the treatment was facilitated with clean classroom, air conditioner, notebook (laptop), film, and music related to building motivation.

3. Distributing the questionnaire.

4. Identifying the result of the questionnaire.

5. Identifying the result of data from the questionnaire.

The collected data were analyzed by using percentage technique, then tabulating and analysing them into descriptive statistic. Each statement in the questionnaire offered five scales namely:
a) strongly agree
b) agree
c) uncertain 
Volume 5, Number 01, June 2019

d) disagree

e) and strongly disagree

The formulating of percentage is:

$$
\mathrm{P}=\frac{\mathrm{F}}{\mathrm{N}} \times 100 \%
$$

Notation:

P: Percentage

F: Frequency

$\mathrm{N}$ : The total number of students

(Subana, Mursetyo, and Sudrajat, 2000: 47)

\section{FINDINGS AND DISCUSSION}

\section{Findings}

The rate percentages of the students' score are:

Item I

\begin{tabular}{|l|l|l|l|}
\hline No & Classification & Frequency & Percentage \\
\hline A & Strongly agree & 2 & $10 \%$ \\
b & Agree & 11 & $55 \%$ \\
c & Uncertain & - & - \\
d & Disagree & 7 & $35 \%$ \\
e & Strongly disagree & - & - \\
\hline \multicolumn{2}{|l|}{ Total } & $\mathbf{2 0}$ & $\mathbf{1 0 0 \%}$ \\
\hline
\end{tabular}

The table shows that some of the students have good interest in learning English before taking course at JILC Perintis. It is provided that 10\% students strongly agree, $55 \%$ students agree, and $35 \%$ students disagree.

Item II

\begin{tabular}{|c|c|c|c|}
\hline No & Classification & Frequency & Percentage \\
\hline $\mathrm{a}$ & Strongly agree & 15 & $75 \%$ \\
\hline b & Agree & 5 & $25 \%$ \\
\hline c & Uncertain & - & - \\
\hline $\mathrm{d}$ & Disagree & - & - \\
\hline e & Strongly disagree & - & - \\
\hline \multicolumn{2}{|c|}{ Total } & 20 & $100 \%$ \\
\hline
\end{tabular}


The table shows that all students agree hypnosis (hypnolearning) to be applied at JILC Perintis. It is provided that $75 \%$ students strongly agree, and $25 \%$ students agree.

\section{Item III}

\begin{tabular}{|c|c|c|c|}
\hline No & Classification & Frequency & Percentage \\
\hline $\mathrm{a}$ & Strongly agree & 15 & $75 \%$ \\
\hline $\mathrm{b}$ & Agree & - & - \\
\hline $\mathrm{c}$ & Uncertain & 5 & $25 \%$ \\
\hline $\mathrm{d}$ & Disagree & - & - \\
\hline e & Strongly disagree & - & - \\
\hline & Total & 20 & $100 \%$ \\
\hline
\end{tabular}

Most of the students strongly agree that hypnosis (hypnolearning) is useful to increase students' ability in English. It is provided on the table above that there are $75 \%$ students who strongly agree and $25 \%$ students are uncertain.

Item IV

\begin{tabular}{|c|c|c|c|}
\hline No & Classification & Frequency & Percentage \\
\hline $\mathrm{a}$ & Strongly agree & 9 & $45 \%$ \\
\hline $\mathrm{b}$ & Agree & 7 & $35 \%$ \\
\hline $\mathrm{c}$ & Uncertain & 3 & $15 \%$ \\
\hline d & Disagree & 1 & $5 \%$ \\
\hline e & Strongly disagree & - & - \\
\hline \multicolumn{2}{|r|}{ Total } & 20 & $100 \%$ \\
\hline
\end{tabular}

Based on the table above, most of students strongly agree that they are more interested in learning English by using hypnosis (hypnolearning). It can be showed on the table's percentage above that there are 9 students who strongly agree, 7 students who agree, 3 students who are uncertain, and just 1 student who disagree.

Item V

\begin{tabular}{|c|c|c|c|}
\hline No & Classification & Frequency & Percentage \\
\hline A & Strongly agree & 16 & $80 \%$ \\
b & Agree & - & $15 \%$ \\
c & Uncertain & 3 & $5 \%$ \\
d & Disagree & 1 & - \\
e & Strongly disagree & - & $\mathbf{1 0 0 \%}$ \\
\hline
\end{tabular}


Volume 5, Number 01, June 2019

Based on the table above, most of the students strongly agree that they are glad to join English lesson if their tutor is good at hypnosis (hypnolearning). It shows that there are 80\% students who strongly agree, $15 \%$ students who are uncertain, and $5 \%$ students who disagree.

\section{Item VI}

\begin{tabular}{|c|c|c|c|}
\hline No & Classification & Frequency & Percentage \\
\hline a & Strongly agree & 10 & $50 \%$ \\
b & Agree & 6 & $30 \%$ \\
c & Uncertain & 3 & $15 \%$ \\
d & Disagree & 1 & $5 \%$ \\
e & Strongly disagree & - & - \\
\hline \multicolumn{2}{|r|}{} & $\mathbf{2 0}$ & $\mathbf{1 0 0 \%}$ \\
\hline
\end{tabular}

The students are enthusiastic if their tutor applies hypnosis (hypnolearning) in teaching English. It is provided on the table that there are 50\% students who strongly agree, $30 \%$ students who agree, $15 \%$ students who are uncertain, and 5\% students who disagree.

\section{Item VII}

\begin{tabular}{|c|c|c|c|}
\hline No & Classification & Frequency & Percentage \\
\hline $\mathrm{a}$ & Strongly agree & 3 & $15 \%$ \\
\hline $\mathrm{b}$ & Agree & 9 & $45 \%$ \\
\hline $\mathrm{c}$ & Uncertain & 8 & $40 \%$ \\
\hline $\mathrm{d}$ & Disagree & - & - \\
\hline e & Strongly disagree & - & - \\
\hline \multicolumn{2}{|r|}{ Total } & 20 & $100 \%$ \\
\hline
\end{tabular}

According to the students, using hypnosis (hypnolearning) in learning English makes them more active to study, to ask, and to answer tutor's questions in learning English. There are 3 students who strongly agree, 9 students who agree, and 8 students who are uncertain.

\section{Item VIII}

\begin{tabular}{|c|c|c|c|}
\hline No & Classification & Frequency & Percentage \\
\hline $\mathrm{a}$ & Strongly agree & 15 & $75 \%$ \\
\hline $\mathrm{b}$ & Agree & 3 & $15 \%$ \\
\hline c & Uncertain & 2 & $10 \%$ \\
\hline $\mathrm{d}$ & Disagree & - & - \\
\hline e & Strongly disagree & - & - \\
\hline \multicolumn{2}{|r|}{ Total } & 20 & $100 \%$ \\
\hline
\end{tabular}


Based on the table above, most students strongly agree that the use of hypnosis (hypnolearning) at JILC can increase students' motivation in learning English. There are $75 \%$ students who strongly agree, 15\% students who agree, and $10 \%$ students who are uncertain.

\section{Item IX}

\begin{tabular}{|c|c|c|c|}
\hline No & Classification & Frequency & Percentage \\
\hline $\mathrm{A}$ & Strongly agree & 12 & $60 \%$ \\
\hline b & Agree & 8 & $40 \%$ \\
\hline $\mathrm{c}$ & Uncertain & - & - \\
\hline d & Disagree & - & - \\
\hline e & Strongly disagree & - & - \\
\hline \multicolumn{2}{|r|}{ Total } & 20 & $100 \%$ \\
\hline
\end{tabular}

According to the students, all of them agree that learning technique with using hypnosis (hypnolearning) should often be applied in the classroom. It is provided on the table above that there are 12 students who strongly agree and 8 students who agree.

Item X

\begin{tabular}{|c|c|c|c|}
\hline No & Classification & Frequency & Percentage \\
\hline $\mathrm{a}$ & Strongly agree & 12 & $60 \%$ \\
\hline $\mathrm{b}$ & Agree & 4 & $20 \%$ \\
\hline $\mathrm{c}$ & Uncertain & 3 & $15 \%$ \\
\hline d & Disagree & 1 & $5 \%$ \\
\hline e & Strongly disagree & - & - \\
\hline \multicolumn{2}{|r|}{ Total } & 20 & $100 \%$ \\
\hline
\end{tabular}

Most of students state that the process of learning English is more interesting if the tutor uses hypnosis. It is provided on the table above that there are 60\% students who strongly agree, $20 \%$ students who agree, $15 \%$ students who are uncertain, and 5\% students who disagree.

Item XI

\begin{tabular}{|c|c|c|c|}
\hline No & Classification & Frequency & Percentage \\
\hline $\mathrm{a}$ & Strongly agree & 6 & $30 \%$ \\
\hline $\mathrm{b}$ & Agree & 10 & $50 \%$ \\
\hline c & Uncertain & 4 & $20 \%$ \\
\hline $\mathrm{d}$ & Disagree & - & - \\
\hline e & Strongly disagree & - & - \\
\hline \multicolumn{2}{|r|}{ Total } & 20 & $100 \%$ \\
\hline
\end{tabular}


Volume 5, Number 01, June 2019

According to the students, 16 students agree that using hypnosis in the classroom can make the lesson easier. English can be easily understood if the tutor utilizes hypnosis in the classroom. It is showed on the table above that there are 6 students who strongly agree, 10 students who agree, and 4 students who are uncertain.

Item XII

\begin{tabular}{|c|c|c|c|}
\hline No & Classification & Frequency & Percentage \\
\hline a & Strongly agree & 4 & $20 \%$ \\
b & Agree & 15 & $75 \%$ \\
c & Uncertain & - & - \\
d & Disagree & 1 & - \\
e & Strongly disagree & - & $\mathbf{1 0 0 \%}$ \\
\hline
\end{tabular}

According to the students, they do not feel bored and tired to participate in the learning process that applies hypnosis. There are 4 students who strongly agree, 15 students who agree, and just 1 student who disagree.

Item XIII

\begin{tabular}{|c|c|c|c|}
\hline No & Classification & Frequency & Percentage \\
\hline $\mathrm{a}$ & Strongly agree & 9 & $45 \%$ \\
\hline $\mathrm{b}$ & Agree & 6 & $30 \%$ \\
\hline c & Uncertain & 5 & $25 \%$ \\
\hline d & Disagree & - & - \\
\hline e & Strongly disagree & - & - \\
\hline \multicolumn{2}{|r|}{ Total } & 20 & $100 \%$ \\
\hline
\end{tabular}

The table shows that the students are more diligent to study English after joining hypnosis (hypnolearning). There are $45 \%$ students who strongly agree, 30\% students who agree, and $25 \%$ students who are uncertain.

Item XIV

\begin{tabular}{|c|c|c|c|}
\hline No & Classification & Frequency & Percentage \\
\hline a & Strongly agree & 9 & $45 \%$ \\
b & Agree & 7 & $35 \%$ \\
c & Uncertain & 3 & $15 \%$ \\
d & Disagree & 1 & $5 \%$ \\
e & Strongly disagree & - & - \\
\hline
\end{tabular}


Learning English is more effective by using hypnosis (hypnolearning). It is provided on the table above that there are $45 \%$ students who strongly agree, $35 \%$ students who agree, 15\% students who are uncertain, and 5\% students who disagree.

\section{Item XV}

\begin{tabular}{|c|c|c|c|}
\hline No & Classification & Frequency & Percentage \\
\hline $\mathrm{a}$ & Strongly agree & 10 & $50 \%$ \\
\hline $\mathrm{b}$ & Agree & 6 & $30 \%$ \\
\hline c & Uncertain & 3 & $15 \%$ \\
\hline d & Disagree & 1 & $5 \%$ \\
\hline e & Strongly disagree & - & - \\
\hline \multicolumn{2}{|r|}{ Total } & 20 & $100 \%$ \\
\hline
\end{tabular}

According to the students, they feel relaxed in learning English by using hypnosis (hypnolearning). It is showed on the table above that there are $50 \%$ students who strongly agree, $30 \%$ students who agree, $15 \%$ students who are uncertain, and 5\% students who disagree.

\section{Item XVI}

\begin{tabular}{|c|c|c|c|}
\hline No & Classification & Frequency & Percentage \\
\hline $\mathrm{a}$ & Strongly agree & 6 & $30 \%$ \\
\hline $\mathrm{b}$ & Agree & 12 & $60 \%$ \\
\hline $\mathrm{c}$ & Uncertain & 2 & $10 \%$ \\
\hline d & Disagree & - & - \\
\hline e & Strongly disagree & - & - \\
\hline \multicolumn{2}{|r|}{ Total } & 20 & $100 \%$ \\
\hline
\end{tabular}

The students really enjoy studying if the tutor uses hypnosis (hypnolearning) in last the lesson. It is provided on the table above that there are 30\% students who strongly agree, $60 \%$ students who agree, and 10\% students who are uncertain.

Item XVII

\begin{tabular}{|c|c|c|c|}
\hline No & Classification & Frequency & Percentage \\
\hline A & Strongly agree & 6 & $30 \%$ \\
\hline b & Agree & 9 & $45 \%$ \\
\hline $\mathrm{c}$ & Uncertain & 5 & $25 \%$ \\
\hline d & Disagree & - & - \\
\hline e & Strongly disagree & - & - \\
\hline \multicolumn{2}{|r|}{ Total } & 20 & $100 \%$ \\
\hline
\end{tabular}


Volume 5, Number 01, June 2019

The students like to study at JILC than at their school because JILC uses hypnosis (hypnolearning). It is proved on the table above that there are $30 \%$ students who strongly agree, $45 \%$ students who agree, and $25 \%$ students who are uncertain.

\section{Item XVIII}

\begin{tabular}{|c|c|c|c|}
\hline No & Classification & Frequency & Percentage \\
\hline $\mathrm{a}$ & Strongly agree & 9 & $45 \%$ \\
\hline $\mathrm{b}$ & Agree & 9 & $45 \%$ \\
\hline c & Uncertain & 2 & $10 \%$ \\
\hline d & Disagree & - & - \\
\hline e & Strongly disagree & - & - \\
\hline & Total & 20 & $100 \%$ \\
\hline
\end{tabular}

According to the students, learning English becomes easier because hypnosis help to make sure that they are in the right state of mind to receive information and recall it later. It is showed on the table above that there are $45 \%$ students who strongly agree, $45 \%$ students who agree, and $10 \%$ students who are uncertain.

Item IX

\begin{tabular}{|c|c|c|c|}
\hline No & Classification & Frequency & Percentage \\
\hline $\mathrm{a}$ & Strongly agree & 7 & $35 \%$ \\
\hline $\mathrm{b}$ & Agree & 7 & $35 \%$ \\
\hline $\mathrm{c}$ & Uncertain & 4 & $20 \%$ \\
\hline d & Disagree & 2 & $10 \%$ \\
\hline e & Strongly disagree & - & - \\
\hline \multicolumn{2}{|r|}{ Total } & 20 & $100 \%$ \\
\hline
\end{tabular}

The students' achievement in English learning both at JILC and at school is improved as a result being taught by hypnosis at JILC. It is provided on the table above that there are $35 \%$ students who strongly agree, $35 \%$ students who agree, $20 \%$ students who are uncertain, and 10\% students who disagree.

\section{Item XX}

\begin{tabular}{|c|c|c|c|}
\hline No & Classification & Frequency & Percentage \\
\hline a & Strongly agree & 13 & $65 \%$ \\
b & Agree & 6 & $30 \%$ \\
c & Uncertain & - & - \\
d & Disagree & 1 & $5 \%$ \\
\hline
\end{tabular}




\begin{tabular}{|c|c|c|c|}
\hline $\mathrm{e}$ & Strongly disagree & - & - \\
\hline & Total & $\mathbf{2 0}$ & $\mathbf{1 0 0 \%}$ \\
\hline
\end{tabular}

In general, most students admit that their motivation in learning English has increased after being taught by using hypnosis. The result has shown that only 1 student out of 20 students disagrees.

\section{Discussion}

This part particularly deals with the elaboration and integration of the research findings. The main focus is to find out whether the use of hypnosis can increase the motivation of the students of STAN 2 who took English course at JILC Perintis. The researcher was a tutor at JILC Perintis, and therefore he decided to take one of his classes as the subject of the research. The research was conducted for one month, in 8 meetings. In one meeting, hypnosis (hypnolearning) was conducted two times because the students studied for two hours. The students studied one hour which was categorized as one meeting, and then the students took a break for 15 minutes. After that, the class was continued for another one hour which was also categorized as one meeting. The total treatments including questionnaire distribution was 8 times for 8 meetings.

To find the objective information about whether or not hypnosis helps to increase students' motivation in learning English, the researcher also distributed related questionnaire to the students. Based on the data analysis of the questionnaire, most students of STAN 2 at JILC Perintis stated that hypnosis has increased their motivation in learning English. It can be seen from the way they responded to every item in the questionnaire. The students mostly responded "strongly agree' and "agree".

The writer compared what he wrote in review of literature and in findings of this research. In review of literature, hypnosis is very useful to increase motivation to reach our goal that we want. In findings, it includes 20 items of questionnaire concern with students' motivation. In short, the statements in review of literature agree with data analysis from questionnaire analysis in findings.

In summary, the researcher concluded that using hypnosis (hypnolearning) has positively contributed to the increase of the students' motivation in learning English. Furthermore, hypnosis (hypnolearning) is eligible to be used in education systems, especially to motivate students in learning. In additions, hypnosis (hypnolearning) not only can be used to increase the students' motivation in learning English but also hypnosis (hypnolearning) can be used to 
increase students' motivation in learning all subjects. Hypnosis can be used in all purposes, it depends on the suggestion that the hypnotist gives to the subjects (people who are hypnotised).

\section{E. CONCLUSIONS AND SUGGESTIONS}

\section{Conclusion}

Based on the data analysis in the research findings, the writer concludes that hypnosis (hypnolearning) can increase students' motivation in learning English. Thus, the teachers can use hypnosis (hypnolearning) as a tool to motivate students in learning process. In addition, hypnosis (hypnolearning) is eligible to use in education system as a tool to motivate students. Hypnosis can be used not only in learning English but also in learning all subjects. Hypnosis (hypnolearning) uses subconscious mind to lose students' negative perception in their brain. Hypnosis (hypnolearning) changes negative thought in subconscious mind to be positive one. Generally, hypnosis can be used to all the things or aspects based on our purposes.

\section{Suggestions}

Based on the conclusion above, the researcher presents some suggestions as follows:

1. The researcher suggests that a teacher or a lecturer must pay attention to students' motivation in learning process (before, during and after the learning process).

2. The researcher suggests that the teacher or the lecturer may consider using hypnosis (hypnolearning) to increase students' motivation in learning English or other subjects in learning process.

3. The researcher suggests that the teachers, lecturers or administrators may apply hypnosis (hypnolearning) at least once during one term, one semester or one year in seminar class or in the classroom teaching both in formal education and in informal education in order to motivate the students in learning the subjects or to help the students change the negative thought into positive.

4. The researcher suggests that the government support and facilitate the implementation of hypnosis (hypnolearning) in all education systems because hypnosis (hypnolearning) is eligible to be used in education systems (in formal educations such as schools, colleges, universities or in informal education such as courses) to motivate students in learning. 


\section{Hamzar, Pogressing Students' Motivation in Learning English....}

5. The researcher suggests that every individual implements self hypnosis as additional hypnosis (hypnolearning) both inside of classroom and outside of classroom for educational objectives or any kinds of positive purposes.

\section{REFERENCES}

Brandon, Jhon. (2009). Terapi hipnotis diri. Jakarta: PT Pustakaraya.

Burrows, G.D., Robb O. Stanley, \& Peter B. Bloom. (2001). International handbook of clinical hypnosis. United Kingdom: John Wiley \& Sons, Ltd.

Gunawan, Adi W..(2007). Hypnoteraphy: The art of subconscious restructuring. Jakarta: PT Gramedia Pustaka Utama.

Hoy, W.K. \& Miskel C.G. (1982). Educational administration: Theory, research, and practice. New York: Random House.

Jamarah, Syaiful Bahri. (2008). Psikologi belajar. Jakarta: Rineka Cipta.

Purwanto, M. Ngalim. (2007). Psikologi pendidikan. Bandung: PT Remaja Rosdakarya.

Putra, Dianata Eka. (2010). Mahir hipnotis dalam 1 hari. Jakarta Selatan: Cetak Buku Publisher.

Rusli, Setia I. \& Johanes Arifin Wijaya. (2009). The secret of hypnosis. Jakarta: Penebar Plus.

Setiawan, Toni. (2009). Hipnotis \& hipnoterapi. Jakarta: Garasi.

Seto, Mario. (2009). 365 Kutipan motivasi kadar tinggi. Jogjakarta: Bookmarks.

Shuttleworth, David. (2004). Mind control NLP \& bypnosis. No Place. No publisher.

Subana, M., Marsetiyo Rehardi, \& Sudrajat. (2000). Statistik pendidikan. Bandung: Pustaka

Uno, Hamzah B..(2008). Teori motivasi dan pengukurannya. Jakarta: PT Bumi Aksara.

Wong, Willy \& Andri Hakim. (2009). Dahsyatnya hipnosis. Jakarta: Visimedia. 